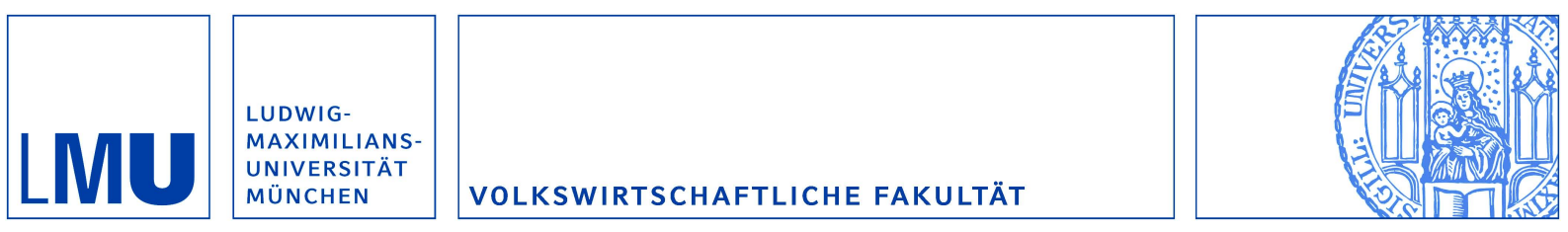

John A., List und Daniel, Sturm:

How Elections Matter: Theory and Evidence from Environmental Policy

Munich Discussion Paper No. 2006-3

Department of Economics

University of Munich

Volkswirtschaftliche Fakultät

Ludwig-Maximilians-Universitäł München

Online at https://doi.org/10.5282/ubm/epub.768 


\title{
HOW ELECTIONS MATTER: THEORY AND EVIDENCE FROM ENVIRONMENTAL POLICY*
}

\author{
John A. List And Daniel M. Sturm
}

November 2005

This paper explores to what extent secondary policy issues are influenced by electoral incentives. We develop a two dimensional political agency model in which a politician decides on both a frontline policy issue and a secondary policy issue. The model predicts when the incumbent should manipulate the secondary policy to attract voters. We test our model by using panel data on environmental policy choices in the U.S. states. In contrast to the popular view that secondary policies are largely determined by lobbying, we find strong effects of electoral incentives.

\section{INTRODUCTION}

One of the defining features of representative democracies is periodic elections. At the end of each term voters have the opportunity to reward the incumbent politician with reelection or to replace him with a challenger. This ability of voters to hold the incumbent accountable for his policy choices should in turn act as a powerful incentive instrument for politicians to conduct policies that voters reward with reelection.

While there is some consensus that the disciplining effect of elections has an impact on "frontline" policy issues such as the level of government spending or the degree of income and wealth redistribution, there is widespread skepticism whether secondary policy issues, that substantially affect only small groups in society, are influenced by electoral

\footnotetext{
*We would like to thank to Robin Burgess, Gene Grossman, Eckhard Janeba, Arik Levinson, Niko Matouschek, Carol McAusland, Alistair Munro, Andrea Prat, Sönje Reiche, James Snyder, Thomas Stratmann, Alistair Ulph, the editors, especially Robert Barro, two anonymous referees, and numerous seminar participants for valuable comments and discussions. We are particularly indebted to Tim Besley for many comments and discussions and for making his data available. We would also like to thank David Kellerman from the U.S. Bureau of the Census for his help with the data on environmental expenditures. email: jlist@uchicago.edu and daniel.sturm@lmu.de
} 
incentives. Typical examples of such secondary policy issues are environmental policy, gun control, foreign aid, or trade policy. This view is fueled by two main arguments. First, political competition is inherently multidimensional - politicians decide on a range of policy issues during each term in office. In the election, however, voters only have the binary option of retaining the incumbent or replacing him with a challenger. Voters are therefore unable to separately sanction specific policy choices of the incumbent. Second, given the multitude of policy issues, voters may find it optimal to remain uninformed about the policy choices of the incumbent on many secondary policy issues that have little impact on them, which further accentuates the lack of electoral accountability.

Scepticism about the importance of elections for secondary policy issues has been a key factor behind the widespread use of lobby models to understand the political economy of such issues. The lobby literature portrays the policymaking process as a strategic interaction between the incumbent and various interest groups, while elections are typically not explicitly modelled. Politicians are assumed to select policies based on their preferences over both financial contributions from lobby groups and social welfare.

In this paper we argue that contrary to this skeptical view, electoral incentives are an important determinant of policy choices on secondary policy issues. The basic idea behind our approach is simple. Voters have heterogeneous preferences over policy issues. While most secondary policies have little impact on the majority of voters, it is likely that there are some voters substantially affected by a particular secondary policy. Their preferences over this policy are strong enough to induce them to be "single-issue voters," that is ones who will vote for the politician considered most likely to implement their preferred policy on this particular issue. This opens the distinct possibility that politicians distort their policy choices in such secondary areas to attract single-issue voters to their platform.

We capture this idea in a simple political agency model. During each term of office an incumbent politician decides on two policy instruments: a frontline policy and a secondary policy. Voters have heterogeneous preferences over these policy instruments. While the majority of voters are indifferent about the secondary policy, there is a small group of voters, who we will refer to as "single-issue voters," for whom the secondary 
policy is more important than the frontline policy. We assume that politicians' preferences over the frontline policy are common knowledge, while there is some uncertainty about their views on the secondary policy. We show under what conditions a simple "reputation building" equilibrium emerges. In this equilibrium even politicians who are privately opposed to the preferred policy of the group of single-issue voters sometimes override their personal preferences and cater to the interests of the single-issue voters. This, in turn, can be sufficient to attract the votes of the single-issue voters in the next election.

We generate our empirical predictions by introducing term limits into the model. The model predicts that during terms in which the incumbent faces a binding term limit, he no longer strategically distorts his policy choices to attract additional voters. The predicted difference in policy choices between terms in which the incumbent can and cannot be reelected depends very intuitively on two key parameters. First, the larger the group of voters whose voting decision depends on the secondary policy, the larger should be the incentive to manipulate this policy. This implies that we should observe a larger variation in the secondary policy between years in which the incumbent can and cannot be reelected if more votes depend on this policy choice. Second, the incentive to distort the secondary policy should also be particularly acute if elections are competitive and attracting additional votes is particularly valuable. This implies that the variation in the secondary policy between years in which the incumbent can and cannot be reelected should be more pronounced if elections are competitive.

We test the predictions of our model using panel data on environmental policy across U.S. states. This setting is in many ways ideal to test our theoretical predictions. First, it seems likely that there are only small groups of voters who have sufficiently intense preferences either in favor or against the environmental policy choice of the incumbent. Second, while some aspects of environmental policy are decided at the federal level, state governments have considerable influence over many environmental policies. Finally, the widespread use of term limits for governors provides us with exogenous variation in the reelection incentives of governors.

We find strong evidence consonant with our theoretical predictions. Our first result is that environmental policy differs considerably between years in which the current gov- 
ernor can be reelected and years in which he faces a binding term limit. Second, we find that the change in environmental policy induced by a binding term limit depends on the composition of the state population in the manner suggested by the theoretical model: in states with large pro-environmental groups we find that governors advance substantially less environmentally-friendly policies when they can no longer be reelected. We observe exactly the opposite pattern in states with small environmental groups, however. In such states we observe that governors advance much greener policies once they face a binding term limit. Finally, we also examine the impact of changes in the degree of political competition on the environmental policy choices of governors. In line with our model, we find strong evidence that governors are substantially less likely to manipulate environmental policy if they enjoy overwhelming support.

There is a voluminous literature on lobby models. Following Grossman and Helpman [1994, 1995] a series of papers has used the menu auction lobby model to explain the determinants of trade policy. Excellent recent surveys of this literature are Helpman [1997] and Grossman and Helpman [2002]. The menu auction lobby model has also generated a large literature on the political economy of environmental policy. Useful recent surveys of this literature are Heyes and Dijkstra [2001] and Oates and Portney [2003]. Examples of other applications of the lobby model are Marceau and Smart [2003], who consider the determination of the equilibrium capital tax rate, and Lahiri and RaimondosMøller [2000], who investigate the impact of lobbying on the allocation of foreign aid.

Apart from the lobby model, variants of the median voter model have been the most popular approach to the political economy of secondary issues (see, e.g., Congleton [1992] and McAusland [2003] in the area of environmentally policy and Mayer [1984] in the case of trade policy). While the median voter model explicitly considers the role of elections for policy choices, we argue that our empirical findings are difficult to reconcile with the median voter model.

The remainder of our study proceeds as follows. Section II introduces the theoretical model and develops the empirical predictions. Section III discusses our empirical strategy and the data. Section IV presents the empirical results. Section V discusses some of the implications of our results for the lobby and median voter models. Section VI concludes. 


\section{THE MODEL}

Our model is in the spirit of the political agency literature that originated with Barro [1973]. Recent contributions to this literature include Coate and Morris [1995], Besley and Case [1995], Banks and Sundaram [1998], and Besley and Burgess [2002]. Our basic approach to modelling multiple policy instruments in a political agency model is similar to Besley and Burgess [2002]. We extend their approach by introducing term limits and examining an infinite horizon model.

\section{II.A. Economic Environment}

A community with $N$ citizens makes two policy decisions. The first policy issue is the level of general public spending $g$. Public spending is financed through a uniform tax on all citizens of the community. The second policy issue is a binary environmental policy $e \in\{0,1\}$, where $e=1$ indicates that the policy has been implemented. The environmental policy has negligible financial implications for the government's budget. Citizens have heterogeneous preferences over both policy issues. We assume that there are four distinct types of citizens $k \in\{L, R, G, B\}$, where $L$ stands for "left-wing," $R$ for "right-wing," $G$ for "green," and $B$ for "brown." The fraction of the population that is of type $k$ is denoted $\gamma_{k}$.

Left-wing and right-wing citizens derive utility from the level of public spending and have a unique preferred level of spending $g^{*}(L)$ and $g^{*}(R)$. We assume that $g^{*}(L)>g^{*}(R)$ and that left- and right-wing citizens are indifferent about the environmental policy. Green citizens receive a payoff of $\Delta>0$ if the environmental policy is undertaken and zero otherwise. Brown citizens in contrast receive a payoff of $\Delta$ if the environmental policy is not undertaken and zero otherwise. Both green and brown citizens are, for simplicity, assumed not to have preferences over the level of public spending $g .{ }^{1}$

Policymaking is delegated to an elected representative. Candidates for office are drawn from two parties, a right-wing party and a left-wing party. Politicians' views on

\footnotetext{
${ }^{1} \mathrm{~A}$ more general assumption that does not change our theoretical predictions would be that green and brown citizens also have preferences over the level of public spending but that the payoff from their preferred environmental policy dominates their payoff from their preferred level of public spending.
} 
the level of public spending $g$ are straightforward: Politicians from the left-wing party always implement $g^{*}(L)$ and politicians from the right-wing party always implement $g^{*}(R)$. Politicians' views on the environmental policy are less predictable. We assume that candidates hold some personal views on the environmental policy which are private knowledge and that a randomly selected candidate from either party is in favor of implementing the environmental policy with probability $\pi .^{2}$ We will refer to politicians who are personally in favor of implementing the environmental policy as "green" politicians and politicians who are personally opposed to the environmental policy as "brown" politicians.

Politicians receive two types of payoffs from holding office (we normalize their utility to zero if they are out of office). The first is an "ego rent" from holding office, $\lambda$. The second is a utility cost $c \in\left\{c_{L}, c_{H}\right\}$ if they do not implement the environmental policy that they personally prefer. We assume that $c_{H}>c_{L}$ and that the probability of costs being low is given by $p$. An important restriction on politicians' preferences is that $c_{H}>\beta \lambda>c_{L}$, where $\beta$ is the discount factor with which both politicians and voters discount future payoffs. This assumption states that the high realization of the utility cost is larger, and the low realization of the utility cost is smaller, than the ego rent from holding office for one more period. The importance of this assumption will become clearer in a moment.

The outcome of the election contains some randomness due to, for example, shocks to turnout, lost ballot boxes, and the like. Let $\omega$ denote the "lead" of party $L$ if there were no random shocks to the election outcome, which is defined as the fraction of the total vote cast in favor of party $L$ in excess of $1 / 2$. Let $\varepsilon$ be a pro-left shock that distributes a fraction $\varepsilon$ of the votes from the right-wing to the left-wing candidate. We assume that $\varepsilon$ is distributed with density $h(\varepsilon)$, which is smooth, symmetric around zero, and singlepeaked, which implies that the shock to the election outcome is unbiased. Furthermore, we assume that the support of $h(\varepsilon)$ is sufficiently wide that there is always some residual uncertainty about the election outcome for any realized value of the lead $\omega .^{3}$ Let $H(\varepsilon)$

\footnotetext{
${ }^{2}$ It would not be difficult to also allow for uncertainty about politicians views on public spending. This would simply introduce another dimension in which politicians could signal their preferences.

${ }^{3} \mathrm{An}$ implication of this assumption is that voters always have a positive probability of affecting the election outcome and therefore always find it optimal to vote if the costs of voting are sufficiently small.
} 
be the cumulative distribution function that is associated with $h(\varepsilon)$. These assumptions imply that a left-wing candidate wins the election with probability $1-H(-\omega)$, which is increasing in $\omega$. Similarly, a right-wing candidate wins the election with probability $1-H(\omega)$, which is decreasing in $\omega$.

\section{II.B. Timing and Equilibrium Definition}

There are an infinite number of periods. Voters are infinitely lived, but politicians face a binding term limit after two periods in office. To simplify matters we also assume that politicians who leave office never return to office. At the beginning of each period nature moves and reveals the cost shock $c \in\left\{c_{L}, c_{H}\right\}$, which is observed only by the incumbent. The incumbent then chooses the level of public spending and whether or not to implement the environmental policy, which is observed by the voters. At the end of each term is an election. If the incumbent does not face a binding term limit, then the election is a contest between the incumbent and a randomly drawn challenger from the opposing party. ${ }^{4}$ If the incumbent faces a binding term limit, then the election is a contest between two randomly selected candidates, one from each party. The winner of the election is in office in the next period and an identical sequence begins.

We characterize Markov Perfect equilibria of the game between politicians and voters, i.e., we restrict attention to strategies that only condition on payoff relevant features of the environment. A strategy for a politician is a rule that specifies the probability $\alpha$ with which he implements the environmental policy $(e=1)$ as a function of the relative size of the group of green and brown voters $\gamma_{G}-\gamma_{B}$, the difference in size of the group of right- and left-wing voters $\left|\gamma_{R}-\gamma_{L}\right|$, the realized utility costs $c$, and the number of terms that he has already spent in office. The strategy of type $k=L$ and $k=R$ voters is a rule which specifies the probability with which they vote for the candidate from the right- or left-wing party. A strategy for a type $k=G$ and $k=B$ voter consists of two parts. First, a probability $\sigma_{k}$ with which he votes for the incumbent in elections that are a contest between the incumbent and a challenger. Second, this probability $\sigma_{k}$ is a function of his updated beliefs about the type the incumbent, denoted $\tilde{\pi}$, which are derived from Bayes

\footnotetext{
${ }^{4}$ We are therefore implicity abstracting from competition between the incumbent and other politicians from the same party.
} 
rule. ${ }^{5}$ These strategies form an equilibrium if they maximize the value functions of the voters and the politicians given the other players' strategies.

\section{II.C. Political Equilibrium}

In solving for the political equilibrium of the game between voters and politicians note that the optimal strategy for $k=L$ and $k=R$ voters must be to vote for the leftwing and right-wing candidate, respectively, since politicians do not act strategically with respect to the level of public spending. We therefore only need to solve for the equilibrium environmental policy choices. We concentrate on the case where $\gamma_{G}>\gamma_{B}$, i.e. where there are more green than brown voters in the population; the case of $\gamma_{G}<\gamma_{B}$ is symmetric. As usual, we solve the environmental policy game by backward induction starting with the second term in office of a politician. Given that the term limit is binding after a politician's second term in office, the dominant strategy for politicians is to implement the environmental policy that they personally prefer in their second term in office.

We now derive under which conditions the following strategies are an equilibrium during a politician's first term in office: green politicians always implement the environmental policy while brown politicians ignore their personal views and implement the environmental policy $(e=1)$ if the cost shock is low $\left(c=c_{L}\right)$ and do not do so otherwise. Furthermore, green voters vote for the incumbent if the environmental policy has been implemented and for the challenger otherwise, while brown voters vote for the incumbent if the environmental policy has not been implemented and for the challenger otherwise.

Given the voters' strategies, the strategy of a green politician is clearly optimal, as implementing the environmental policy is both his preferred policy choice and increases his reelection probability by attracting the votes of the green citizens. The strategy of a brown politician must also be optimal if $c=c_{H}$ due to our assumption that $\beta \lambda<c_{H}$. This assumption ensures that compromising on the environmental policy when the utility cost is high cannot be outweighed by the benefits of an additional term in office, $\beta \lambda$.

Now consider the incentives of a left-wing politician who is opposed to implementing

\footnotetext{
${ }^{5}$ In elections that are a contest between two untried politicians green and brown voters must be indifferent. Whatever voting strategy green and brown voters adopt in this case has no impact on the testable implications of the model that we focus on.
} 
the environmental policy. If he implements the environmental policy he attracts the votes of the left-wing voters and the green voters, and wins the election with probability $1-H\left[-\left(\gamma_{L}+\gamma_{G}-\frac{1}{2}\right]\right.$. If he does not implement the environmental policy, he attracts the votes of the left-wing voters and the brown voters, and wins with probability 1 $H\left[-\left(\gamma_{L}+\gamma_{B}-\frac{1}{2}\right]\right.$. The difference in the reelection probabilities between these two policy choices simplifies to

$$
\int_{-\left(\gamma_{L}+\gamma_{G}-\frac{1}{2}\right)}^{-\left(\gamma_{L}+\gamma_{B}-\frac{1}{2}\right)} h(\varepsilon) d \varepsilon \equiv \Gamma\left(\gamma_{G}-\gamma_{B}\right) .
$$

The symmetry of $h(\varepsilon)$ implies that, for given values of $\gamma_{L}$ and $\gamma_{R}, \Gamma\left(\gamma_{G}-\gamma_{B}\right)$ is also the increase in the reelection probability of a right-wing politician if he implements the environmental policy. The payoff from implementing the environmental policy therefore generates an expected payoff of $\Gamma\left(\gamma_{G}-\gamma_{B}\right) \beta \lambda$ for both left- and right-wing brown politicians, which must be larger than $c_{L}$ for the strategy to be optimal.

In the appendix we show that the strategy of green and brown voters to vote for the incumbent if he has implemented their preferred policy is also optimal given the politicians' strategy if

$$
\pi+(1-\pi) p<\frac{\pi}{\pi+(1-\pi) p} .
$$

Note that this condition is always satisfied for sufficiently small values of $p$. Condition (2) states that politicians who have implemented the environmental policy in their first term must be more likely to implement the environmental policy in their second term in office than a randomly selected politician in his first term in office. Finally, the appendix also shows that the equilibrium that we have now established is the unique equilibrium in this parameter range. The results of this discussion are summarized in the following proposition:

Proposition 1. If condition (2) holds and $\Gamma\left(\gamma_{G}-\gamma_{B}\right) \beta \lambda>c_{L}$, there is a unique equilibrium in which politicians faced with a low-cost shock override their private preferences on the environmental policy in their first term in office if this increases their reelection probability, and follow their private preferences otherwise.

We will refer to the equilibrium characterized in Proposition 1 as the "reputation building" equilibrium. In this equilibrium, politicians use the environmental policy to 
build a reputation with green and brown voters. If there are more green than brown voters, then politicians who are personally opposed to implementing the environmental policy have an incentive to nevertheless undertake environmental policy during their first term in office in order to attract green voters. Similarly, if there are more brown voters than green voters, then incumbents who are in favor of implementing the environmental policy have an incentive to act anti-environmentally in order to attract brown voters. Finally, it is not difficult to see that politicians do not undertake reputation-building and instead always implement their preferred policy outside the parameter range characterized in Proposition 1.

The reputation-building equilibrium characterized in Proposition 1 depends on two key parameters of the model. First, consider an increase in the number of votes that the incumbent can attract by distorting the environmental policy, i.e. an increase in $\left|\gamma_{G}-\gamma_{B}\right|$. This makes it more likely that the incumbent finds it worthwhile to undertake reputation building. The reason is that the change in his reelection probability from attracting the votes of the single-issue voters $\Gamma\left(\gamma_{G}-\gamma_{B}\right)$ is increasing in $\left|\gamma_{G}-\gamma_{B}\right|$ and it is therefore more likely that the condition $\Gamma\left(\gamma_{G}-\gamma_{B}\right) \beta \lambda>c_{L}$ is satisfied. ${ }^{6}$ Second, consider the effect of a decrease in $\left|\gamma_{L}-\gamma_{R}\right|$, which makes the election more competitive. This also makes it more likely that the incumbent engages in reputation building. This is due to our assumption that the distribution of shocks to the election outcome $h(\varepsilon)$ is symmetric around zero and single-peaked. This implies that $\Gamma\left(\gamma_{G}-\gamma_{B}\right)$ reaches a maximum as $\left|\gamma_{L}-\gamma_{R}\right|$ approaches zero and it is therefore more likely that $\Gamma\left(\gamma_{G}-\gamma_{B}\right) \beta \lambda>c_{L}$ is satisfied. This discussion is summarized in the following proposition:

Proposition 2. An increase in the number of votes that can be attracted by distorting the environmental policy or an increase in the competitiveness of elections makes it more likely that incumbents engage in reputation building.

\section{II.C. Empirical Implications}

Propositions 1 and 2 characterize the incentive effect that elections have on the behavior of politicians with respect to environmental policy and imply three testable

\footnotetext{
${ }^{6}$ Note that a decrease in $c_{L}$ would have a completely equivalent effect.
} 
implications of the model. ${ }^{7}$ The first and most basic implication of the model is that environmental policy should differ between years in which the incumbent can and cannot be reelected. The intuition is that incumbents who have distorted environmental policy during their first term in office to increase their reelection chances will no longer do so during their second term in office when the term limit is binding.

The second empirical implication is that this temporal variation should differ between green states, where $\gamma_{G}>\gamma_{B}$, and brown states, where $\gamma_{G}<\gamma_{B}$. In the reputationbuilding equilibrium, in green states even incumbents personally opposed to the environmental policy will undertake the environmental policy during their first term if $c=c_{L}$, but never do so in their second term when the term limit binds. Exactly the opposite should be true in brown states, where incumbents in favor of the environmental policy chose not to implement it during their first term if $c=c_{L}$, but always implement it in their second term in office. In brown (green) states, therefore, politicians facing a binding term limit should on average undertake more (less) environmental policy than they undertook in their non-term limited years.

The third empirical implication of the model, which follows immediately from Proposition 2, is that any such difference in environmental policy between years in which the incumbent can and years in which the incumbent cannot be reelected should decrease when the degree of political competition lessens. The intuition is that an incumbent's incentive to build a reputation in order to attract additional votes should be small if he is likely to be reelected in any case.

\section{EMPIRICAL Strategy AND DATA}

An ideal testing ground for the predictions of our model is the behavior among U.S.

\footnotetext{
${ }^{7}$ In this model, elections also have a simple selection effect. In a green state, for example, green politicians have a higher reelection probability in the political equilibrium than brown politicians, as they always implement the environmental policy (not only when $c=c_{L}$ ). This implies that the sample of politicians in their second term is biased towards politicians in favor of environmental policy. This selection effect could in principle dominate the incentive effect characterized in Proposition 1 . However, the selection effect becomes arbitrarily small as $\gamma_{G}-\gamma_{B}$ approaches zero, as distorting the environmental policy has an arbitrarily small impact on the outcome of the election in this case. We will assume that the groups of green and brown voters are sufficiently small that the selection effect is dominated by the incentive effect of elections. Our empirical findings below support this assumption. See List and Sturm [2004] for further discussion of this point.
} 
governors, who have substantial influence in many policy areas. In particular the implementation of environmental policy is to a large extent delegated to state governments. Furthermore, many U.S. states have term limitations for their governors. Table I provides an overview of the term limit legislation for U.S. governors between 1970 and 2000, showing that in many states governors face binding term limits after a certain period in office, usually two terms. The regular occurrence of binding term limits provides us with a source of exogenous variation in the reelection incentives of the governor. The general strategy of our empirical analysis is to compare the environmental policy choices of governors who can be reelected to a further term in office to those of governors who will be removed from office by a binding term limit. In particular, we test whether the differences in policy choices between these two groups are in line with the predictions of our model.

\section{III.A. Data}

To measure the environmental policy stance of the governor, we use state expenditure data in the 48 continental U.S. states from 1970 to $2000 .^{8}$ The census of state governments reports three expenditure categories, which cover most of state environmental spending. These are expenditures on "fish and game," "forests and parks," and "other natural resources." All three spending categories record very similar expenditures which are likely to be close substitutes for voters both in favor and opposed to environmental policy. We therefore use the sum of these three expenditure categories in per capita amounts and deflated to 1982-1984 dollars as our basic measure of the environmental policy stance of the governor. These three expenditure categories account in our sample for about 1.8 percent of state total general spending. We have also experimented with three alternative indicators of governors' environmental policy stance. First, we assembled data on state health expenditures. Second, we use the index of state environmental compliance costs constructed in Levinson [2001]. Finally, we also examined two environmental outcome measure, which are state average $\mathrm{SO}_{2}$ and $\mathrm{NO}_{x}$ emissions.

Our key explanatory variable is a dichotomous variable, which is equal to one if the current governor faces a binding term limit, and zero otherwise. Both this variable

\footnotetext{
${ }^{8}$ As usual in the literature using state level data, we exclude Alaska and Hawaii.
} 
and control variables for state personal income, state population, the percentage of the population over 65 and the percentage of the population between 5 and 17 are updated versions of the data used in Besley and Case [1995, 2003].

To capture the prediction of the model that the incentives of the governor to distort environmental policy will depend on the size of the group of voters who have intense preferences in favor of environmental policy, we have obtained data on the number of members in the three largest environmental organizations, which are Greenpeace, Friends of the Earth, and the Sierra Club as a percentage of the state population. We were able to obtain membership data for 1987 and 2000. Since membership figures across these two years are highly positively correlated, and 1987 is roughly in the middle of our sample period we use the 1987 membership. Membership in these organizations varies considerably across states from a maximum of just over two percent of the population in Vermont to a minimum of .25 percent in Mississippi. ${ }^{9}$ We do not have a direct measure of the size of the anti-environmental constituency in each state, so we use the number of members in the top three environmental organizations as a proxy for the relative strength of green and brown voters in a state. This is a valid approach if, for example, the number of green and brown voters is uncorrelated or even negatively correlated. We will see that our empirical results suggest that this does not seem to be an unreasonable assumption.

The final implication of our theoretical model, that governors should have less of an incentive to manipulate policies to attract additional votes if they are likely to be reelected in any case, requires a measure of the governor's current support in the electorate. A simple proxy for the governor's current electoral support is his vote share in the most recent gubernatorial election. We therefore construct a variable "margin" which is equal to the percentage share of the governor in the vote that went to the top two candidates in the most recent gubernatorial election (minus 50 percent) to measure his current electoral support. ${ }^{10}$ Table II provides means and standard deviations of our variables split across

\footnotetext{
${ }^{9}$ The ten states with the largest proportion of the population organized in Greenpeace, Friends of the Earth, and the Sierra Club in 1987 (in descending order) are Vermont, New Hampshire, Connecticut, California, Colorado, Maine, Massachusetts, Oregon, Delaware and New Jersey. Those with the lowest membership levels are South Carolina, Tennessee, Texas, West Virginia, Oklahoma, Kentucky, Arkansas, Louisiana, Alabama and Mississippi.

${ }^{10}$ While an advantage of this approach is that we have a measure that should closely track the governor's current reelection prospects, a potential concern is that this measure is endogenous. Section IV considers
} 
states with and without term limits. Appendix 2 contains detailed references to the data sources.

\section{III.B. Empirical Strategy}

Our basic empirical approach is a simple difference-in-differences specification which is similar to that used in Besley and Case [1995] and other empirical work using state-level data

$$
e n v_{i t}=a+\delta l_{i t}+\beta X_{i t}+\alpha_{i}+\varphi_{t}+t_{i}+\varepsilon_{i t}
$$

where $e n v_{i t}$ is our indicator of the governor's environmental policy stance in state $i$ at time $t$. The regressor of primary interest is the indicator variable $l_{i t}$, which equals one whenever the current governor faces a binding term limit and is therefore a "lame duck," and zero otherwise. Additional regressors are state fixed effects $\alpha_{i}$, time fixed effects $\varphi_{t}$, and also a set of state-specific time trends $t_{i}$. For our basic results vector $X_{i t}$ contains the same control variables as in Besley and Case [1995]. These are the total state population, state personal income per capita, the percentage of the population between 5 and 17, and the percentage of the population over 65 . Finally, $\varepsilon_{i t}$ is the contemporaneous error term. To assess the robustness of our findings we also experiment with more extensive sets of control variables and allow for the possibility of both heteroskedasticity and arbitrary correlation of the error term within each state.

The coefficient $\delta$ in (3) captures the basic prediction of our theoretical model, that environmental policy should differ between terms in which the incumbent governor can and cannot be reelected to another term in office. Yet the model also suggests that $\delta$ should depend on the relative size of the groups of green and brown voters, i.e. whether $\gamma_{G}-\gamma_{B}>0$ or $\gamma_{G}-\gamma_{B}<0$. To examine empirically this hypothesis we create an indicator variable for green states that is equal to one if the proportion of the state's residents who are members of Greenpeace, Friends of the Earth, and the World Wildlife Fund exceeds an arbitrary cutoff level, and is equal to zero otherwise. For our basic results we classify the eight states with the largest membership levels as green. Below we return to this choice of cutoff and perform extensive sensitivity tests.

a number of modifications of our measure of the closeness of elections to address this problem. 
The indicator variable for green states allows us to extend (3) by interacting this variable with the indicator for a governor facing a binding term limit $l_{i t}$. In this extended regression the coefficient of $l_{i t}$ captures the difference in environmental policy between terms in which the governor can and cannot be reelected in states that we have classified as brown. Our theoretical model predicts that this coefficient should be positive as some governors in brown states will be catering to the anti-environmental tastes of their constituents if they can run for reelection, but will cease to do so once they face a binding term limit. Similarly, the sum of the coefficient of $l_{i t}$ and its interaction with our indicator variable for green states captures the same change in the behavior of governors in green states. Our theoretical model predicts that this sum should be negative as governors who are catering to the pro-environmental interests in these states when they can run for reelection will reduce environmental spending once they become lame ducks. ${ }^{11}$

The final prediction of the theoretical model is that $\delta$ should also differ systematically with the degree of political competition. In periods with little political competition (i.e. periods in which $\left|\gamma_{L}-\gamma_{R}\right|$ is substantially different from zero), governors should display less of a change in behavior between terms in which they can and cannot be reelected. The reason is that a governor who holds a significant advantage over challengers, should have less of an incentive to manipulate secondary policies, even if he can run for reelection. To capture this notion, we first ignore the heterogeneity between green and brown states and interact the indicator for a lame duck governor $l_{i t}$ with our measure of the governor's current support ("margin") and also enter this variable as a level regressor. Our model predicts that this interaction term should take the opposite sign as the coefficient $\delta$, i.e. higher levels of support for the governor should reduce the effect of a binding term limit.

Our final specification combines both the effects of the degree of political competition and the difference between green and brown states. This specification includes both our indicator for a lame duck governor $l_{i t}$, our measure of the governor's current support as a level regressor and interacted with $l_{i t}$, and also interaction terms between these three

\footnotetext{
${ }^{11}$ Note that we cannot include our indicator variable for a green state as a level regressor as it does not have any time variation, and therefore its inclusion combined with the inclusion of state fixed effects would cause the rank condition to be violated.
} 
variables and our indicator variable for green states. These three interactions capture the difference in the governor's response to a binding term limit between brown states (the baseline in our model) and green states. In sum, our empirical model is therefore able to test the major implications of our model: during lame duck years governors "undo" secondary policies enacted earlier in their governorships to attract voters, and the nature and extent of this reversal depends critically on the composition of constituencies and the competitiveness of elections.

\section{Results}

Table III contains a summary of our basic estimation results. Column 1 estimates the baseline specification (3). We find that governors who face a binding term limit increase environmental expenditure per capita by approximately $\$ 0.79$, and this effect is statistically significant at conventional levels. Relative to the sample mean, this change represents an increase in environmental spending of nearly three percent. Column 2 extends the basic specification by allowing the effect of a binding term limit to differ between green and brown states. In line with the predictions of the model, we find that in states that we classify as brown (our baseline), environmental spending per capita increases by an even larger amount $(\$ 1.12)$ if the incumbent governor cannot be reelected, but we observe the opposite pattern in states that we classify as green. In this case the sum of the coefficients for our indicator of a binding term limit and its interaction with our indicator for a green state suggests that environmental expenditures are roughly 6.3 percent lower relative to the sample mean when the governor is a lame duck. These results are consonant with the notion that lame duck governors reverse policies that they enacted to attract additional voters once they face a binding term limit.

Column 3 in Table III allows the term limit effect to depend on the competitiveness of gubernatorial elections. Both the indicator for a binding term limit and its interaction with our measure of the closeness of elections have the expected opposite signs and are statistically significant at conventional levels, implying that in states where political competition is less strong, the governor has less incentive to manipulate policies. For example, the empirical estimates imply that a governor who had a share of about 67 
percent of the vote implements the same environmental policy regardless of whether he faces another election or will be forced out of office by a binding term limit. In line with our theoretical model, elections do not seem to influence environmental policy choices when the votes of green or brown voters are unlikely to influence to outcome of the election.

The final column in Table III combines the effect of the size of green and brown groups and the competitiveness of elections. All coefficients have the expected sign and are statistically significant at conventional levels. Empirical estimates of the indictor of a binding term limit and its interaction with our measure of competitiveness of elections suggest that in brown states governors who cannot be reelected increase environmental spending by approximately 9.2 percent if elections are competitive. Furthermore, governors who had a vote share of approximately 70 percent of the last election do not exhibit any difference in behavior between terms in which they can and cannot be reelected. In green states, however, governors reduce environmental spending by about 20 percent if they cannot be reelected and this difference disappears if the governor gained roughly 65 percent of the vote in the last election.

Table IV presents a number of robustness checks of our results. In a recent paper, Bertrand et al. [2004] criticize simple difference-in-differences estimates for ignoring autocorrelation in data from the U.S. states, which can result in substantially inflated t-values. While our basic specification already includes state-specific time trends, which should address some of this problem, we now also allow for arbitrary correlations of the error term within each state by clustering the standard errors in each state. Additionally, we also include a more extensive set of control variables, which not only includes state personal income per capita, state population, the fraction of the population over 65 and the fraction of the population between 5 and 17 linearly, but also squared and cubed and a full set of interaction terms between these variables. Column 1 of Table IV shows that this change has only a marginal impact on the size and statistical significance of the coefficients.

Column 2 restricts the sample to the period 1975-2000. The beginning of the 1970s marked a substantial increase in environmental concern in the U.S., as witnessed by the 
creation of the Environmental Protection Agency and the first Earth Day, which attracted 20 million citizens to peacefully demonstrate for environmental reform. Consistent with this our estimated effects are even larger if we restrict to the years after 1975. Column 3 investigates to what extent our results depend on the behavior of governors who face oneterm limits and finds that the results are largely unchanged. The next column excludes all observations without term limit legislation, which help to identify the fixed effects and other control variables. This reduces the sample size considerably, but the estimates remain remarkably stable.

The last six columns of Table IV consider a number of modifications of our measure of the closeness of elections to address the potential endogeneity of this variable. The main concern is that a governor's vote share in the last election could be correlated with his underlying preferences for environmental policy. First, in contrast to our assumption that the probability of a randomly selected governor being in favor of environmental policy is a constant, green and brown voters might receive a noisy signal of the views on environmental policy of potential candidates for the governorship, which influences their voting decision. This problem alone would only bias the estimates of our measure of competition as a level regressor, but would not invalidate our strategy of comparing the change in behavior between terms in which the incumbent can and cannot be reelected. The second, and more serious, concern is that our theoretical model suggests that the governor's decisions on environmental policy during a term in office will be reflected in his vote share in the election at the end of this term, which we are using to gauge the support of the governor during his next term in office.

To address this problem, we adopt two strategies. First, columns 5 and 6 of Table IV convert our measure of the closeness of elections into a dummy variable, which is equal to one if the variable is above its median. While the votes of green and brown voters will have some impact on the governor's vote share, a substantial part of the variation in this variable will be due to other factors. Green and brown votes are therefore less likely to influence this modified measure of the closeness of elections. Empirical results are very similar to our previous findings. The statistical significance is substantially better in column 6, where we restrict the sample to the 1975-2000 period. 
Our second strategy is to eliminate the time variation in our measure of the closeness of elections within each governor's spell in office, by replacing it with the governors average vote share. Results in columns 7 and 8 are also very similar to our previous findings. ${ }^{12}$ The final two columns of Table IV combine both of these approaches by converting a governor's average vote share into a dummy variable, which is equal to one if this variable is above its median. In this specification we are identifying via a very limited part of the variation in governors' vote shares and any remaining influence of the voting behavior of green and brown voters on this variable should be minimal. The results are again remarkably similar to our previous findings.

Our sensitivity analysis of the results with respect to the classification of states as green is presented in Table V. This table makes liberal changes to the cutoff for classification of a state as green. The pattern that emerges from this sensitivity analysis is intuitive. In column one of Table $\mathrm{V}$, only the six states with the largest environmental groups as a proportion of the state's population are classified as green. Relative to our baseline specification, which is repeated in column 2 of Table $\mathrm{V}$, the lower level of environmental expenditures in green states during term limit years is now even more pronounced. As we increase the number of states that are classified as green, the fall in environmental spending induced by a binding term limit in these states becomes smaller and loses statistical significance.

At the same time the increase in environmental spending in states classified as brown if the governor cannot be reelected increases in size as fewer states are classified as brown. In the final column in Table $\mathrm{V}$, for example, only the six states with the smallest proportion of the population organized in the three largest environmental organizations are classified as brown and the results for this specification suggest that environmental spending is almost 20 percent higher relative to the sample mean when the governor cannot be reelected and elections are highly competitive. This pattern seems to suggest that our assumption that we can approximate the difference in size between green and brown groups with the number of members in the three largest environmental organiza-

\footnotetext{
${ }^{12}$ We have also experimented with using a governor's first election result instead of his average margin. While the results are broadly comparable, a governor's first election result seems to be a much noisier proxy for his overall popularity than his average margin.
} 
tions is empirically plausible. If anything, the absence of large green groups appears to be correlated with the presence of substantial groups of brown voters.

We have also investigated to what extent our results depend on our measure of the environmental policy stance of the governor. We have examined three alternative measures. First, we have used state health expenditures per capita, which also captures some aspects of environmental policy making. We find that the results for health spending are very similar to those for our base measure used above. Second, we have used the index of state abatement costs developed in Levinson [2001], which is only available for a much shorter period of time, as our dependent variable. Remarkably, we find statistically significant effects of the governors' electoral incentives not only on expenditures items but also on this measure of abatement costs. Finally, we have also used $\mathrm{SO}_{2}$ and $N O_{x}$ emissions as a dependent variable. These results are also consistent with our basic findings, but are only statistically significant at conventional levels for $\mathrm{SO}_{2}$ in the period after $1975 . .^{13}$

\section{Discussion}

In this section we discuss the implications of our findings for the literature using the lobbying model or the median voter model and also previous research on the effects of term limits. It is difficult to envision how our empirical findings can be reconciled with the median voter approach, in that it is hard to imagine a mechanism that could generate systematic changes in the identity or preferences of the median voter that could explain the variation in environmental policy that we document. This is particularly so as the median voter model is one of pre-election politics, where politicians commit to a particular policy platform before the election and simply implement their platform once they have been elected. In such a model the presence or absence of a further election at the end of a politician's current term in office is therefore by assumption irrelevant for policy choices in the current term. Our results call into question this assumption.

The most widely used approach in the literature has been various lobbying models. Particularly influential have been applications of the well-known menu auction model of

\footnotetext{
${ }^{13}$ See List and Sturm [2004] for further robustness tests, including disaggregated results using expenditure on fish and game, forests and parks, and other natural resources as separate dependent variables.
} 
lobbying developed in Grossman and Helpman [1994] in the context of trade policy. In this model the government maximizes a weighted sum of lobby contributions and social welfare. Lobbies compete with each other and offer the incumbent contribution schedules that are contingent on the incumbent's policy choices. It is also difficult to see how the standard lobby model could account for our empirical findings as it does not explicitly model the impact of elections on policy choices. ${ }^{14}$

While it may be possible to extend the lobby model by, for example, endogenizing the weight that the government attaches to social welfare or considering intertemporal strategies of the lobbies, such extensions of the model hinge on the assumption that the main influence of green lobby groups on environmental policy choices is through financial contributions. This seems unrealistic. The Institute on Money in State Politics, for example, reports that in 1998, which was an election year in all of the eight states that we classified as green for our basic results, contributions from pro-environmental groups in the gubernatorial races amounted to a total of $\$ 26,856$ in those eight states. In contrast, donations from electric utilities and the oil and gas industry, as two examples of polluting industries, alone amounted to a total of $\$ 837,122$ and $\$ 1,097,620$, respectively in the same eight states. ${ }^{15}$ Hence, even in states that we classified as green, polluting industries seem to outspend environmental groups by several orders of magnitude and it is difficult to see how environmental groups could substantially influence policy through financial contributions alone. ${ }^{16}$

Our conclusion is therefore that while lobby contributions must undoubtedly be an important factor behind policy choices in many areas, it seems difficult to deny that politicians implement policies not only to attract contributions, but also to attract additional voters to their platform. While our model focuses entirely on the role of policies

\footnotetext{
${ }^{14}$ Several recent papers, including Goldberg and Maggi [1999], Gawande and Bandyopadhyay [2000], and Eicher and Osang [2002] empirically test the lobby model on data from trade policy choices. We are not aware of any work that has tested the menu auction model with data from environmental policy.

${ }^{15}$ Computed from the information on campaign contributions on the Institute on Money in State Politics' webpage at www.followthemoney.org.

${ }^{16} \mathrm{~A}$ similar picture emerges from data on contributions to the U.S. Congress which is available from the Center for Responsive Politics at www.opensecrets.org. During the 1990s contributions from electric utilities and the oil and gas industry alone were roughly 10 times as large as the contributions from environmental organizations.
} 
as a way to attract additional votes, a promising avenue for future research would be to develop models that explicitly account for the way in which policy choices can be used to attract both votes and contributions. ${ }^{17}$

In their seminal paper, Besley and Case [1995] used term limit legislation to investigate how governors who face a binding term limit change total state spending and state tax revenue. Their main finding was that incumbents who can no longer be reelected increased total state spending and total tax revenue. They reported changes in total spending and total taxes of between one and two percent relative to their sample mean. This contrasts with our findings that the presence of a binding term limit changes environmental spending in many specifications by over 10 percent. One possible explanation for this considerable difference in the magnitude of the effects is that it is easier for a governor to reallocate expenditures rather than to increase the overall size of the state budget. To investigate these issues, we have re-estimated all of our specifications with the share of environmental spending in total state spending as the dependent variable. Empirical results are statistically significant and suggest that most of the changes in environmental spending that we observe are indeed due to reallocations of expenditure, rather than to changes in the overall size of the state budget.

\section{CONCLUSION}

In this paper we have developed a two-dimensional political agency model. Politicians, who face periodic elections, decide on the level of public spending and on environmental policy. Our theoretical model suggests that politicians may use environmental policy to attract either environmental or anti-environmental voters. As this incentive is absent in periods in which the incumbent faces a binding term limit, our model predicts that environmental policy should vary systematically between years in which the incumbent can and years in which the incumbent cannot be reelected. In particular, we show how this variation depends on the size of environmental groups and the competitiveness of elections.

\footnotetext{
${ }^{17} \mathrm{~A}$ first step in this direction is Grossman and Helpman [1996]. In their model policy choices affect a group of informed voters, while campaign contributions can be used to "impress" a group of uninformed voters. One of the main predictions of their model is that special interests become more influential as political competition decreases, which is difficult to square with our empirical findings.
} 
We test these predictions by analyzing behavior of U.S. governors over the 1970-2000 period. We find substantial empirical support for the predictions of our model. First, we find that environmental policy differs substantially between years in which the governor can and cannot be reelected. Second, we find that whether environmentally-friendly policy advances or retracts once electoral incentives are removed depends critically on the composition of the electorate. In states with a large group of green voters we find that governors advance less environmentally-friendly policies once they face a binding term limit. We observe the opposite pattern in states with a small environmental constituency, where governors advance much greener policies once they can no longer be reelected. These results suggest that governors reverse policies that they have undertaken purely to attract voters once they face a binding term limit. Finally, the degree to which governors change their environmental policy between terms in which they can and cannot be reelected is systematically related to the degree of political competition, suggesting that less pandering is done by governors with overwhelming support.

A provocative conclusion from our results is that in contrast to the received wisdom that elections are likely to only influence aggregate policy instruments, such as the level of total government spending or the degree of wealth redistribution, our findings suggest that exactly the opposite might be the case - it is secondary policies such as environmental policy, which constitutes only a small share of state expenditure, that politicians seem to find much easier to manipulate in response to electoral competition. 


\section{Appendix 1: Proof Proposition 1}

The main text establishes the optimality of the politician's strategies. We now show that the reelection rule of green and brown voters is also optimal. The value function for a green voter is

$$
V_{G}=v_{G}^{1}(\pi)+\beta \sum_{e} \max _{\sigma_{G}^{e}}\left[f\left(\sigma_{G}^{e}\right)\left(v_{G}^{2}\left(\tilde{\pi}^{e}\right)+\beta V_{G}\right)+\left(1-f\left(\sigma_{G}^{e}\right)\right) V_{G}\right]
$$

where $v_{G}^{1}(\pi)$ and $v_{G}^{2}\left(\tilde{\pi}^{e}\right)$ are a green voter's utility during the incumbent's first and second term in office. The latter depends on his updated beliefs $\tilde{\pi}^{e}$ about the incumbent's type after observing policy choice $e$. Furthermore, $\sigma_{G}^{e}$ is the probability that a green citizen votes for the incumbent if the incumbent's first period policy choice was $e$. The voter's reelection probability $\sigma_{G}^{e}$ enters the value function as the argument of a function $f($.$) as his voting decision is not decisive, but only changes the reelection probability of$ the incumbent. It is straightforward to verify that $f($.$) is increasing and continuous under$ the assumptions of our model.

Inspection of (4) reveals that for $\sigma_{G}^{e}=1$ to be an optimal response it has to be the case that $v_{G}^{2}\left(\tilde{\pi}^{e}\right)+\beta V_{G} \geq V_{G}$, which simplifies to

$$
v_{G}^{2}\left(\tilde{\pi}^{e}\right) \geq(1-\beta) V_{G}
$$

Note that under the equilibrium strategies of the politicians, $v_{G}^{1}=\pi x+(1-\pi) p x, v_{G}^{2}\left(\tilde{\pi}^{0}\right)=$ 0 and $v_{G}^{2}\left(\tilde{\pi}^{1}\right)=\pi /[\pi+(1-\pi) p]$. Also, it must be the case that $V_{G} \geq v_{G}^{1}(\pi) /(1-\beta)$, which is the continuation payoff that the voter would realize if he never reelected any incumbent. Substituting this into (5) implies that it would have to be the case that $v_{G}^{2}\left(\tilde{\pi}^{0}\right) \geq v_{G}^{1}(\pi)$ for $\sigma_{G}^{0}=1$ to be an optimal response. As, however $v_{G}^{2}\left(\tilde{\pi}^{0}\right)<v_{G}^{1}(\pi)$, the optimal response must be $\sigma_{G}^{0}=0$. To show that $\sigma_{G}^{1}=1$ is the optimal response note that the voter's continuation payoff must be smaller than $v_{G}^{2}\left(\tilde{\pi}^{1}\right) /(1-\beta)$ under the equilibrium strategies of the politicians. Substituting this into (5) implies that $\sigma_{G}^{1}=1$ must be the optimal response.

To show that the equilibrium is unique consider a green state (where $\gamma_{G}>\gamma_{B}$ ). Recall that for green politicians $e=1$ and for brown politicians $e=0$ is a dominant strategy if $c=c_{H}$. Furthermore, note that in the case of $c=c_{L}$ a necessary condition for a green politician to deviate from $e=1$ in his first term in office is $\sigma_{G}^{1}<\sigma_{G}^{0}$. Similarly, 
for a brown politician to deviate from $e=0$ in his first term in office it is necessary that $\sigma_{G}^{0}<\sigma_{G}^{1}$. From this follows that in any equilibrium at most one type of politician deviates from his preferred policy during his first term in office. Consider first that brown politicians implement $e=1$ with less than probability one when $c=c_{L}$. For this to be an equilibrium it would have to be the case that $\sigma_{G}^{1} \beta \lambda-c_{L}=\sigma_{G}^{0} \beta \lambda$, which implies that $c_{L}=\left(\sigma_{G}^{1}-\sigma_{G}^{0}\right) \beta \lambda$. It is straightforward to check with the argument developed above that a green voter's optimal reelection strategy is also in this case to set $\sigma_{G}^{1}=1$ and $\sigma_{G}^{0}=0$, which results in a contradiction as we assume that $\beta \lambda>c_{L}$. Similarly, equilibria in which green politicians implement $e=1$ with less than probability one would require that $c_{L}=\left(\sigma_{G}^{0}-\sigma_{G}^{1}\right) \beta \lambda$. This is also impossible, as the voter's optimal strategy in this case is to set $\sigma_{G}^{1}=1$ and $\sigma_{G}^{0}=0$. The argument for a brown state (where $\gamma_{B}>\gamma_{G}$ ) is analogous.

\section{Appendix 2: DAta Sources}

Our data on state expenditures were supplied by the Bureau of the Census in electronic format and originally appeared in the annual Census publication State Government Finances. The Census defines expenditure on fish and game as expenditure for the "conservation, improvement, development, and propagation of fish and game resources; and the regulation and enforcement of fish and game laws and rules." Expenditure on forests and parks are reported as separate expenditure categories from 1977 onwards, which we aggregated to obtain a consistent time series. Expenditure on forests is defined as expenditure for the "conservation, development, management, and protection of forests and forest resources; regulation and inspection of forest products and industries; and provision of assistance to private or local government owners of woodlands." Similarly, expenditure on parks is defined as the "provision and support of recreational and cultural-scientific facilities maintained for the benefit of residents and visitors." Expenditure on other natural resources support the "conservation, promotion, and development of natural resources (soil, water, energy, minerals, etc.) and the regulation of industries which develop, utilize, or affect natural resources. [It also] covers activities not reported in other Natural Resources functions." 
Expenditure on health is defined as expenditure for the "provision of services for the conservation and improvement of public health." One example of such an expenditure is the "regulation of air and water quality, sanitary engineering, and other environmental health activities." Our measure of state abatement costs is the industry-adjusted index of state environmental compliance costs developed in Levinson [2001]. Finally, state emissions of $\mathrm{NO}_{x}$ and $\mathrm{SO}_{2}$ were obtained from United States Environmental Protection Agency [1995].

Membership in Greenpeace, the World Wildlife Fund, and the Sierra Club as a percentage of the population of each state in 1987 is reported in Institute for Southern Studies [1991]. Our measure of the competitiveness of elections is constructed from the historical tables on gubernatorial election results contained in Scammon et. al. [2001] and Congressional Quarterly [1998]. Election results are unavailable for governors which have succeeded to office and for the 1983 and 1987 gubernatorial races in Louisiana, when no general election was held. This affects 40 observations which we exclude from all regressions. Information on the term limit legislation for governors and whether the current governor faces a binding term limit was taken from Besley and Case [1995, 2003] and complemented with the information in The Book of the States and Kallenbach and Kallenbach [1977]. The proportion of the population over 65 and the proportion of the population between 5 and 17, are also the same as in Besley and Case [2003] and were original taken from the Statistical Abstract of the United States. Information on the population and personal income in each state was obtained from the Bureau of the Census in electronic format at www.census.org. State income and all expenditure categories were deflated with the CPI for all urban consumers (with the average 1982-1984 prices as the base) from the Bureau of Labor Statistics.

\section{University of Chicago and National Bureau of Economic Research University of Munich and Centre for Economic Policy Research}




\section{REFERENCES}

Banks, Jeffrey and Rangarajan Sundaram, "Optimal Retention in Agency Problems," Journal of Economic Theory, LXXXII (1998), 293-323.

Barro, Robert, "The Control of Politicians: An Economic Model," Public Choice, XIV (1973), 19-42.

Bertrand, Marianne, Esther Duflo, and Sendhil Mullainathan, "How Much Should We Trust Differences-in-Differences Estimates?" Quarterly Journal of Economics, CXIX (2004), 249-275.

Besley, Timothy, and Robin Burgess, "The Political Economy of Government Responsiveness: Theory and Evidence from India," Quarterly Journal of Economics, CXVII (2002), 1415-1452.

Besley, Timothy, and Anne Case, "Does Electoral Accountability Affect Economic Policy Choices? Evidence from Gubernatorial Term Limits," Quarterly Journal of Economics, CX (1995), 769-798.

_ Journal of Economic Literature, XLI (2003), 7-73.

Coate, Stephen, and Stephen Morris, "On the Form of Transfers to Special Interests," Journal of Political Economy, CIII (1995), 1210-1235.

Congleton, Roger, "Political Institutions and Pollution Control," Review of Economics and Statistics, LXXIV (1992), 412-421.

Congressional Quarterly, Gubernatorial Elections: 1787-1997 (Washington, DC: Congressional Quarterly, 1998).

Council of State Governments, The Book of the States (Lexington, KY, various years).

Eicher, Theo, and Thomas Osang, "Protection for Sale: An Empirical Investigation: A Comment," American Economic Review, XCII (2002), 1702-1711.

Gawande, Kishore, and Usree Bandyopadhyay, "Is Protection for Sale? Evidence on the Endogenous Protection Source," Review of Economics and Statistics, LXXXII (2000), 139-152. 
Goldberg, Pinelopi, and Giovanni Maggi, "Protection for Sale: An Empirical Investigation," American Economic Review, LXXXIX (1999), 1135-1355.

Grossman, Gene, and Elhanan Helpman, "Protection for Sale," American Economic Review, LXXXIV (1994), 833-850. , "Trade Wars and Trade Talks," Journal of Political Economy, CIII (1995), 675-708. , "Electoral Competition and Special Interest Politics," Review of Economic Studies, LXIII (1996), 265-286.

, Interest Groups and Trade Policy (Princeton, NJ: Princeton University Press, 2002).

Helpman, Elhanan, "Politics and Trade Policy," in Advances in Economics and Econometrics: Theory and Applications, David Kreps and Kenneth Wallis, eds. (Cambridge, MA: Cambridge University Press, 1997).

Heyes, Anthony, and Bouwe Dijkstra, "Interest Groups and the Demand for Environmental Policy," in International Yearbook of Environmental and Resource Economics 2001/2002, Tom Tietenberg and Henk Folmer, eds. (Cheltenham: Edward Elgar, 2001).

Institute for Southern Studies, Green Index (Washington, DC: Island Press, 1991).

Kallenbach, Joseph, and Jessamine Kallenbach, American State Governors 1776-1976 (Dobbs Ferry, NY: Oceana Publications, 1977).

Lahiri, Sajal, and Pascalis Raimondos-Møller, "Lobbying by Ethnic Groups and Aid Allocation," Economic Journal, CX (2000), 62-79.

Levinson, Arik, "An Industry-Adjusted Index of State Environmental Compliance Costs," in Behavioral and Distributional Effects of Environmental Policy, Gilbert Metcalf and Carlo Carraro, eds. (Chicago, IL: University of Chicago Press, 2001).

List, John A. and Daniel M. Sturm, "How Elections Matter: Theory and Evidence from Environmental Policy," NBER Working Paper No. 10609, 2004.

Marceau, Nicolas, and Michael Smart, "Corporate Lobbying and Commitment Failure in Capital Taxation," American Economic Review, XCIII (2003), 241-251. 
Mayer, Wolfgang, "Endogenous Tariff Formation," American Economic Review, LXXIV (1984), 970-985.

McAusland, Carol, "Voting for Pollution Policy: The Importance of Income Inequality and Trade," Journal of International Economics, LXI (2003), 425-451.

Oates, Wallace, and Paul Portney, "The Political Economy of Environmental Policy," in Handbook of Environmental Economics, Karl-Göran Mäler and Jeffrey Vincent, eds. (Amsterdam: North-Holland/Elsevier Science, 2003).

Scammon, Richard, Alice McGillivray, and Rhodes Cook, America Votes 24: A Handbook of Contemporary American Election Statistics (Washington, DC: Congressional Quarterly, 2001).

United States Bureau of the Census, State Government Finances (Washington, DC, various years).

_ Statistical Abstract of the United States (Washington, DC, various years).

United States Environmental Protection Agency, Office of Air Quality Planning and Standards, National Air Pollutant Emission Trends, 1900-1994 (Washington, DC, 1995). 


\section{TABLE I}

Term Limits for Governors by State (1970-2000)

States with no term limits:

CT, ID ${ }^{\mathrm{a}}$, IL, IA, MA ${ }^{\mathrm{b}}, \mathrm{MN}, \mathrm{NH}, \mathrm{NY}, \mathrm{ND}, \mathrm{TX}, \mathrm{VT}, \mathrm{WA}^{\mathrm{c}}, \mathrm{WI}$

States limiting governors to one term in office:

VA

States limiting governors to two terms in office:

AL, DE, FL, LA, MD, ME, MO, NE, NJ, NV, OH, OK, OR, PA, SD, WV

State law changed from no term limit to a three-term limit:

UT (1994)

State law changed from no term limit to a two-term limit:

AZ (1992), AR (1992), CA (1990), CO (1990), KS (1972), MI (1992),

MT (1992), RI (1994), WY (1992)

State law changed from a one-term limit to a two-term limit:

GA (1976), IN (1972), KY (1994), NM (1991), MS (1994), NC (1977), SC (1980), TN (1978)

The year in brackets is the year in which the term limit legislation changed. (a) A two-term limit was passed in 1994, but repealed in 2002. (b) Term limits were enacted in 1994 but were declared unconstitutional by the Idaho Supreme Court in 1997. (c) Enacted a two-term limit in 1992, which was declared unconstitutional by the Washington Supreme Court in 1998. 
TABLE II

Summary Statistics

\begin{tabular}{lccc}
\hline \hline & $(1)$ & $(2)$ & $(3)$ \\
& All Observations & $\begin{array}{c}\text { Observations } \\
\text { without term } \\
\text { limit legislation }\end{array}$ & $\begin{array}{c}\text { Observations } \\
\text { with term limit } \\
\text { legislation }\end{array}$ \\
\hline Environmental Expenditure per Capita & 27.09 & 27.95 & 26.52 \\
(in 1982-1984 Dollars) & $(17.08)$ & $(17.89)$ & $(16.51)$ \\
Governor Faces a Binding Term Limit & 0.27 & 0.00 & 0.44 \\
("Lame Duck") & $(0.44)$ & $(0.00)$ & $(0.50)$ \\
Membership in Greenpeace, WWF and & 0.85 & 1.00 & 0.74 \\
Sierra Club as a Percentage of the Population & $(0.36)$ & $(0.39)$ & $(0.29)$ \\
Margin of the Governor & 8.40 & 7.88 & 8.74 \\
& $(7.74)$ & $(6.66)$ & $(8.36)$ \\
State Personal Income per Capita & 12.93 & 13.22 & 12.73 \\
(in thousands of 1982-1984 Dollars) & $(2.55)$ & $(2.64)$ & $(2.47)$ \\
State Population (in millions) & 4.99 & 5.49 & 4.66 \\
Percentage Population over 65 & $(5.24)$ & $(6.31)$ & $(4.36)$ \\
Percentage Population between 5 and 17 & 11.78 & 11.52 & 11.94 \\
Observations & $(2.03)$ & $(1.89)$ & $(2.10)$ \\
\hline \hline
\end{tabular}

Standard deviations in parentheses. See the text for detailed variable definitions and the data appendix for references to the sources of the data. 
TABLE III

Electoral Accountability and Environmental Policy: Basic Results

\begin{tabular}{|c|c|c|c|c|}
\hline & $\begin{array}{l}\text { (1) } \\
\text { Environmental } \\
\text { expenditure per } \\
\text { capita }\end{array}$ & $\begin{array}{l}\text { (2) } \\
\text { Environmental } \\
\text { spending per } \\
\text { capita }\end{array}$ & $\begin{array}{l}\text { (3) } \\
\text { Environmental } \\
\text { spending per } \\
\text { capita }\end{array}$ & $\begin{array}{c}\text { (4) } \\
\text { Environmental } \\
\text { spending per } \\
\text { capita }\end{array}$ \\
\hline Lame Duck & $\begin{array}{l}0.789 * * \\
(0.368)\end{array}$ & $\begin{array}{l}1.119 * * \\
(0.393)\end{array}$ & $\begin{array}{l}1.749 * * \\
(0.583)\end{array}$ & $\begin{array}{l}2.484 * * \\
(0.612)\end{array}$ \\
\hline Lame Duck $\times$ Green State & & $\begin{array}{l}-2.832 * * \\
(1.100)\end{array}$ & & $\begin{array}{l}-7.914 * * \\
(1.580)\end{array}$ \\
\hline Lame Duck $\times$ Margin & & & $\begin{array}{l}-0.102 * * \\
(0.046)\end{array}$ & $\begin{array}{l}-0.119 * * \\
(0.047)\end{array}$ \\
\hline $\begin{array}{l}\text { Lame Duck } \times \text { Margin } \\
\times \text { Green State }\end{array}$ & & & & $\begin{array}{l}0.461 * * \\
(0.168)\end{array}$ \\
\hline Margin & & & $\begin{array}{c}0.060 \\
(0.038)\end{array}$ & $\begin{array}{c}0.036 \\
(0.040)\end{array}$ \\
\hline Margin $\times$ Green State & & & & $\begin{array}{c}0.149 \\
(0.110)\end{array}$ \\
\hline State Personal Income & $\begin{array}{l}-0.091 \\
(0.852)\end{array}$ & $\begin{array}{l}-0.138 \\
(0.853)\end{array}$ & $\begin{array}{l}-0.131 \\
(0.849)\end{array}$ & $\begin{array}{l}-0.189 \\
(0.848)\end{array}$ \\
\hline State Population & $\begin{array}{c}2.180 \\
(1.453)\end{array}$ & $\begin{array}{c}2.017 \\
(1.459)\end{array}$ & $\begin{array}{c}2.116 \\
(1.427)\end{array}$ & $\begin{array}{c}1.809 \\
(1.417)\end{array}$ \\
\hline $\begin{array}{l}\text { Percentage Population } \\
\text { over } 65\end{array}$ & $\begin{array}{c}0.288 \\
(1.166)\end{array}$ & $\begin{array}{c}0.284 \\
(1.174)\end{array}$ & $\begin{array}{c}0.243 \\
(1.160)\end{array}$ & $\begin{array}{c}0.211 \\
(1.165)\end{array}$ \\
\hline $\begin{array}{l}\text { Percentage Population } \\
\text { between } 5 \text { and } 17\end{array}$ & $\begin{array}{l}-0.408 \\
(0.273)\end{array}$ & $\begin{array}{l}-0.401 \\
(0.273)\end{array}$ & $\begin{array}{l}-0.370 \\
(0.272)\end{array}$ & $\begin{array}{l}-0.388 \\
(0.273)\end{array}$ \\
\hline State fixed effects & Yes & Yes & Yes & Yes \\
\hline Time fixed effects & Yes & Yes & Yes & Yes \\
\hline State-specific time trends & Yes & Yes & Yes & Yes \\
\hline Observations & 1448 & 1448 & 1448 & 1448 \\
\hline R-squared & 0.89 & 0.89 & 0.89 & 0.89 \\
\hline
\end{tabular}

Robust standard errors in parentheses. * indicates significance at the 10 percent level and ** significance at the 5 percent level. For our basic results we classify the 8 states with the largest membership in Greenpeace, the World Wildlife Fund, and the Sierra Club as a percentage of the state population as "Green States." These states are Vermont, New Hampshire, Connecticut, California, Colorado, Maine, Massachusetts and Oregon. See the text for detailed variable definitions and the data appendix for references to the sources of the data. 
TABLE IV

Electoral Accountability and Environmental Policy: Robustness

\begin{tabular}{|c|c|c|c|c|c|c|c|c|c|c|}
\hline & $\begin{array}{c}(1) \\
\text { Environ- } \\
\text { mental } \\
\text { expenditure } \\
\text { per capita }\end{array}$ & $\begin{array}{c}(2) \\
\text { Environ- } \\
\text { mental } \\
\text { expenditure } \\
\text { per capita }\end{array}$ & $\begin{array}{c}(3) \\
\text { Environ- } \\
\text { mental } \\
\text { expenditure } \\
\text { per capita }\end{array}$ & $\begin{array}{c}(4) \\
\text { Environ- } \\
\text { mental } \\
\text { expenditure } \\
\text { per capita }\end{array}$ & $\begin{array}{c}(5) \\
\text { Environ- } \\
\text { mental } \\
\text { expenditure } \\
\text { per capita }\end{array}$ & $\begin{array}{c}(6) \\
\text { Environ- } \\
\text { mental } \\
\text { expenditure } \\
\text { per capita }\end{array}$ & $\begin{array}{c}(7) \\
\text { Environ- } \\
\text { mental } \\
\text { expenditure } \\
\text { per capita }\end{array}$ & $\begin{array}{c}(8) \\
\text { Environ- } \\
\text { mental } \\
\text { expenditure } \\
\text { per capita }\end{array}$ & $\begin{array}{c}(9) \\
\text { Environ- } \\
\text { mental } \\
\text { expenditure } \\
\text { per capita }\end{array}$ & $\begin{array}{c}(10) \\
\text { Environ- } \\
\text { mental } \\
\text { expenditure } \\
\text { per capita }\end{array}$ \\
\hline Lame Duck & $\begin{array}{l}2.447 * * \\
(0.870)\end{array}$ & $\begin{array}{l}2.844^{* *} \\
(0.815)\end{array}$ & $\begin{array}{l}1.989 * * \\
(0.821)\end{array}$ & $\begin{array}{l}2.287 * * \\
(1.036)\end{array}$ & $\begin{array}{l}2.080^{* *} \\
(0.975)\end{array}$ & $\begin{array}{l}2.890^{* *} \\
(1.036)\end{array}$ & $\begin{array}{l}2.214 * * \\
(1.107)\end{array}$ & $\begin{array}{l}3.200^{* *} \\
(1.015)\end{array}$ & $\begin{array}{l}2.225^{* *} \\
(1.010)\end{array}$ & $\begin{array}{l}2.878^{* *} \\
(1.006)\end{array}$ \\
\hline Lame Duck $\times$ Green State & $\begin{array}{l}-7.769 * * \\
(2.368)\end{array}$ & $\begin{array}{c}-11.740^{* *} \\
(1.961)\end{array}$ & $\begin{array}{l}-7.489 * * \\
(2.251)\end{array}$ & $\begin{array}{l}-9.598 * * \\
(1.189)\end{array}$ & $\begin{array}{l}-4.805 \\
(3.347)\end{array}$ & $\begin{array}{c}-11.076^{* *} \\
(1.810)\end{array}$ & $\begin{array}{l}-4.339 \\
(3.677)\end{array}$ & $\begin{array}{c}-10.346^{* *} \\
(4.643)\end{array}$ & $\begin{array}{l}-3.842 \\
(3.025)\end{array}$ & $\begin{array}{l}-7.042 * * \\
(2.350)\end{array}$ \\
\hline Lame Duck $\times$ Margin & $\begin{array}{l}-0.119 * * \\
(0.049)\end{array}$ & $\begin{array}{l}-0.151^{* *} \\
(0.056)\end{array}$ & $\begin{array}{l}-0.095^{* *} \\
(0.046)\end{array}$ & $\begin{array}{l}-0.125^{* *} \\
(0.061)\end{array}$ & $\begin{array}{l}-1.393 \\
(1.227)\end{array}$ & $\begin{array}{l}-2.519 * * \\
(1.280)\end{array}$ & $\begin{array}{l}-0.114 \\
(0.093)\end{array}$ & $\begin{array}{l}-0.210^{* *} \\
(0.082)\end{array}$ & $\begin{array}{l}-1.934 \\
(1.418)\end{array}$ & $\begin{array}{l}-2.834 * * \\
(1.316)\end{array}$ \\
\hline $\begin{array}{l}\text { Lame Duck } \times \text { Margin } \times \\
\text { Green State }\end{array}$ & $\begin{array}{l}0.504^{*} \\
(0.259)\end{array}$ & $\begin{array}{l}0.696^{* *} \\
(0.250)\end{array}$ & $\begin{array}{l}0.467 * \\
(0.255)\end{array}$ & $\begin{array}{l}0.903 * * \\
(0.186)\end{array}$ & $\begin{array}{c}3.203 \\
(4.496)\end{array}$ & $\begin{array}{l}8.370 * * \\
(2.996)\end{array}$ & $\begin{array}{c}0.225 \\
(0.440)\end{array}$ & $\begin{array}{c}0.771 \\
(0.580)\end{array}$ & $\begin{array}{c}2.562 \\
(3.809)\end{array}$ & $\begin{array}{c}4.708 \\
(3.226)\end{array}$ \\
\hline Margin & $\begin{array}{c}0.040 \\
(0.053)\end{array}$ & $\begin{array}{c}0.052 \\
(0.065)\end{array}$ & $\begin{array}{c}0.035 \\
(0.053)\end{array}$ & $\begin{array}{c}0.068 \\
(0.058)\end{array}$ & $\begin{array}{c}0.011 \\
(0.817)\end{array}$ & $\begin{array}{c}0.169 \\
(1.024)\end{array}$ & $\begin{array}{c}0.035 \\
(0.080)\end{array}$ & $\begin{array}{c}0.023 \\
(0.112)\end{array}$ & $\begin{array}{c}1.128 \\
(1.163)\end{array}$ & $\begin{array}{c}1.167 \\
(1.255)\end{array}$ \\
\hline Margin $\times$ Green State & $\begin{array}{c}0.104 \\
(0.201)\end{array}$ & $\begin{array}{c}0.113 \\
(0.207)\end{array}$ & $\begin{array}{c}0.116 \\
(0.200)\end{array}$ & $\begin{array}{l}-0.369^{*} \\
(0.218)\end{array}$ & $\begin{array}{c}1.319 \\
(2.363)\end{array}$ & $\begin{array}{c}2.528 \\
(2.279)\end{array}$ & $\begin{array}{c}0.239 \\
(0.252)\end{array}$ & $\begin{array}{c}0.311 \\
(0.264)\end{array}$ & $\begin{array}{c}0.284 \\
(2.484)\end{array}$ & $\begin{array}{c}2.927 \\
(2.168)\end{array}$ \\
\hline Period & $1970-2000$ & $1975-2000$ & $1970-2000$ & $1970-2000$ & $1970-2000$ & $1975-2000$ & $1970-2000$ & $1975-2000$ & $1970-2000$ & $1975-2000$ \\
\hline Notes & & & $\begin{array}{c}\text { no } \\
\text { observations } \\
\text { with one- } \\
\text { term limits }\end{array}$ & $\begin{array}{c}\text { only } \\
\text { observations } \\
\text { with term } \\
\text { limits }\end{array}$ & $\begin{array}{l}\text { margin } \\
\text { converted } \\
\text { into a } \\
\text { dummy }\end{array}$ & $\begin{array}{l}\text { margin } \\
\text { converted } \\
\text { into a } \\
\text { dummy }\end{array}$ & $\begin{array}{l}\text { average } \\
\text { margin of } \\
\text { governor }\end{array}$ & $\begin{array}{l}\text { average } \\
\text { margin of } \\
\text { governor }\end{array}$ & $\begin{array}{l}\text { average } \\
\text { margin con- } \\
\text { verted into a } \\
\text { dummy }\end{array}$ & $\begin{array}{l}\text { average } \\
\text { margin con- } \\
\text { verted into a } \\
\text { dummy }\end{array}$ \\
\hline Observations & 1448 & 1214 & 1317 & 873 & 1448 & 1214 & 1448 & 1214 & 1448 & 1214 \\
\hline R-squared & 0.89 & 0.90 & 0.90 & 0.94 & 0.89 & 0.90 & 0.89 & 0.90 & 0.89 & 0.90 \\
\hline
\end{tabular}

Standard errors which are robust against heteroskedasticity and are adjusted for clustering at the state level in parentheses. * indicates significance at the 10 percent level and $* *$ significance at the 5 percent level. All regressions include - in addition to state fixed effects, time fixed effects and state-specific time trends - an extended set of controls, which consists of state personal income, state population, percentage of the population over 65 , percentage of the population between 5 and 17 both linearly, squared, and cubed, and a full set of interaction terms between these four controlls. 
TABLE V

Electoral Accountability and Environmental Policy: Changing the Cutoff for Classification as a "Green State"

\begin{tabular}{|c|c|c|c|c|c|c|c|c|}
\hline & $\begin{array}{c}(1) \\
\text { Environ- } \\
\text { mental } \\
\text { expenditure } \\
\text { per capita }\end{array}$ & $\begin{array}{c}(2) \\
\text { Environ- } \\
\text { mental } \\
\text { expenditure } \\
\text { per capita }\end{array}$ & $\begin{array}{c}(3) \\
\text { Environ- } \\
\text { mental } \\
\text { expenditure } \\
\text { per capita }\end{array}$ & $\begin{array}{c}(4) \\
\text { Environ- } \\
\text { mental } \\
\text { expenditure } \\
\text { per capita }\end{array}$ & $\begin{array}{c}(5) \\
\text { Environ- } \\
\text { mental } \\
\text { expenditure } \\
\text { per capita }\end{array}$ & $\begin{array}{c}(6) \\
\text { Environ- } \\
\text { mental } \\
\text { expenditure } \\
\text { per capita }\end{array}$ & $\begin{array}{c}(7) \\
\text { Environ- } \\
\text { mental } \\
\text { expenditure } \\
\text { per capita }\end{array}$ & $\begin{array}{c}(8) \\
\text { Environ- } \\
\text { mental } \\
\text { expenditure } \\
\text { per capita }\end{array}$ \\
\hline Lame Duck & $\begin{array}{l}2.674 * * \\
(0.869)\end{array}$ & $\begin{array}{l}2.447 * * \\
(0.870)\end{array}$ & $\begin{array}{l}2.120^{* *} \\
(0.838)\end{array}$ & $\begin{array}{l}2.152 * * \\
(0.822)\end{array}$ & $\begin{array}{l}2.526^{* *} \\
(1.027)\end{array}$ & $\begin{array}{r}2.566^{*} \\
(1.521)\end{array}$ & $\begin{array}{l}4.245^{* *} \\
(2.106)\end{array}$ & $\begin{array}{l}5.034^{*} \\
(2.886)\end{array}$ \\
\hline Lame Duck $\times$ Green State & $\begin{array}{l}-10.154^{* *} \\
(1.722)\end{array}$ & $\begin{array}{l}-7.769 * * \\
(2.368)\end{array}$ & $\begin{array}{l}-3.975 \\
(4.252)\end{array}$ & $\begin{array}{l}-4.055 \\
(3.891)\end{array}$ & $\begin{array}{l}-2.618 \\
(2.718)\end{array}$ & $\begin{array}{l}-1.464 \\
(2.062)\end{array}$ & $\begin{array}{l}-3.135 \\
(2.407)\end{array}$ & $\begin{array}{l}-3.859 \\
(3.106)\end{array}$ \\
\hline Lame Duck $\times$ Margin & $\begin{array}{l}-0.150^{* *} \\
(0.056)\end{array}$ & $\begin{array}{l}-0.119 * * \\
(0.049)\end{array}$ & $\begin{array}{l}-0.132 * * \\
(0.052)\end{array}$ & $\begin{array}{l}-0.135^{* *} \\
(0.055)\end{array}$ & $\begin{array}{l}-0.154 * * \\
(0.071)\end{array}$ & $\begin{array}{l}-0.099 \\
(0.078)\end{array}$ & $\begin{array}{l}-0.195 * * \\
(0.082)\end{array}$ & $\begin{array}{l}-0.221^{* *} \\
(0.102)\end{array}$ \\
\hline $\begin{array}{l}\text { Lame Duck } \times \text { Margin } \times \\
\text { Green State }\end{array}$ & $\begin{array}{l}0.790 * * \\
(0.152)\end{array}$ & $\begin{array}{l}0.504^{*} \\
(0.259)\end{array}$ & $\begin{array}{c}0.373 \\
(0.285)\end{array}$ & $\begin{array}{c}0.384 \\
(0.245)\end{array}$ & $\begin{array}{c}0.192 \\
(0.192)\end{array}$ & $\begin{array}{c}0.034 \\
(0.143)\end{array}$ & $\begin{array}{c}0.136 \\
(0.128)\end{array}$ & $\begin{array}{c}0.162 \\
(0.138)\end{array}$ \\
\hline Margin & $\begin{array}{c}0.074 \\
(0.058)\end{array}$ & $\begin{array}{l}0.040 \\
(0.053)\end{array}$ & $\begin{array}{c}0.045 \\
(0.054)\end{array}$ & $\begin{array}{c}0.049 \\
(0.063)\end{array}$ & $\begin{array}{c}0.072 \\
(0.061)\end{array}$ & $\begin{array}{c}0.006 \\
(0.059)\end{array}$ & $\begin{array}{c}0.085 \\
(0.054)\end{array}$ & $\begin{array}{c}0.089 \\
(0.069)\end{array}$ \\
\hline Margin $\times$ Green State & $\begin{array}{l}-0.125 \\
(0.119)\end{array}$ & $\begin{array}{c}0.104 \\
(0.201)\end{array}$ & $\begin{array}{c}0.069 \\
(0.182)\end{array}$ & $\begin{array}{c}0.032 \\
(0.126)\end{array}$ & $\begin{array}{l}-0.029 \\
(0.118)\end{array}$ & $\begin{array}{c}0.069 \\
(0.096)\end{array}$ & $\begin{array}{l}-0.037 \\
(0.092)\end{array}$ & $\begin{array}{l}-0.040 \\
(0.091)\end{array}$ \\
\hline Cutoff for "Green State" & $\begin{array}{c}\text { Top } 6 \text { states } \\
1448\end{array}$ & $\begin{array}{c}\text { Top } 8 \text { states } \\
1448\end{array}$ & $\begin{array}{c}\text { Top } 10 \text { states } \\
1448\end{array}$ & $\begin{array}{c}\text { Top } 15 \text { states } \\
1448\end{array}$ & $\begin{array}{c}\text { Top } 25 \text { states } \\
1448\end{array}$ & $\begin{array}{c}\text { Top } 35 \text { states } \\
1448\end{array}$ & $\begin{array}{c}\text { Top } 40 \text { states } \\
1448\end{array}$ & $\begin{array}{c}\text { Top } 42 \text { states } \\
1448\end{array}$ \\
\hline R-squared & 0.89 & 0.89 & 0.89 & 0.89 & 0.89 & 0.89 & 0.89 & 0.89 \\
\hline
\end{tabular}

Standard errors which are robust against heteroskedasticity and are adjusted for clustering at the state level in parentheses. $*$ indicates significance at the 10 percent level and ** significance at the 5 percent level. All regressions include the same set of control variables as in Table IV. 